\title{
Reinvention of tradition as an urban image: the case of Ankara Citadel
}

\author{
Asuman Türkün Erendil, Zuhal Ulusoy \\ Bilkent University, Department of Landscape Architecture and Urban Design 06533, Ankara, \\ Turkey; e-mail: erendil@bilkent.edu.tr, ulusoy@bilkent.edu.tr \\ Received 25 July 2001; in revised form 14 January 2002
}

\begin{abstract}
Debates on urban tourism have been coupled with a widespread discourse on 'placelessness', 'loss of identity', and 'standardization' related to the modernist ideology of planning. In this respect, utilizing this historic urban fabric has become important as a means of recreating an urban image. Ironically, efforts to avoid standardization are caught in another trap of sameness and blandness, because a very similar vocabulary is used in the ability of those tourist-historic places to meet the expectations of the universal tourist industry. In this context, we analyzed the recent efforts to integrate an inner-city area, Ankara Citadel and its vicinity, focusing on the changing identity owing to the introduction of income-generating and tourist-attraction facilities. The nature and consequences of this transformation have been investigated in terms of the issues of preservation practice, economic feasibility, public interest, and its ethics and legitimacy.
\end{abstract}

\section{Introduction}

At the turn of the 21st century quite a large number of cities are restructuring from places of production into places of consumption in the global economy, and services appear to provide the basis of their expansion (Harvey, 1987; Zukin, 1991). Within this process, urban tourism has gained an important role as an economic development strategy, and cities have started to search for some defined niches within the globalized circuits of tourism by investing in their underutilized assets or by 'manufacturing' new identities to become attractive (Fainstein and Judd, 1999). As has been observed in many cases, middle-income and high-income groups abandon central urban areas leaving behind decaying inner-city zones which house mostly the poorest segments of the population. In addition, central city governments of industrial cities, now faced with decreasing tax revenues because of the dislocation of manufacturing jobs and shrinking populations, have to compete with other cities and even with their suburbs in attracting different kinds of businesses and households. Consequently, the search for new tax revenues has had several spatial implications on urban areas through renewal programs (Smith, 1986). These include consumption-oriented gentrification of innercity neighborhoods for the new middle-class, downtown redevelopment, rehabilitation and restoration of historic areas, waterfront developments, and the transformation of old industrial districts to new uses for leisure and entertainment. In addition, local governments have started to encourage and assist investment projects for sports stadia for international sporting events, cultural districts, convention centers, and marketplaces to attract different kinds of domestic and especially foreign tourists for tax reasons (Beauregard, 1998).

During this process, historic preservation and environmental movements have gained momentum and have had the indirect effect of contributing to the increase in tourist attraction sites which arouse feelings of nostalgia and curiosity for citizens who have left behind the city center for suburban housing or for people who are in search of novelty and excitement. The widespread discourse on 'placelessness', 'loss of identity', and 'standardization' related to the modernist ideology of planning (Jacobs, 1961); and 
the interest in the historic urban fabric as a new urban image, coupled with the dictates of economic difficulties faced by many national and local governments, have put their imprint on urban development policies. Ironically, efforts to avoid the standardization of the modern era have been caught in another trap of sameness and blandness, through the use of a very similar vocabulary in the appearance of those tourist-historic places to meet the expectations of the universal tourist industry (Philo and Kearns, 1993). Despite the intention of emphasizing unique and authentic qualities, in many cases the promotion of historic heritage has been based on the demands of an average tourist whose expectations are more or less established owing to advertising and the media.

In this context, we have investigated the transformation of an inner-city area, the Ankara Citadel and its vicinity, to discuss the validity and legitimacy of the current changes and the proposed scenario. This area, which used to be the core of Ankara in the early 1990s, has lost its importance as the city has developed in different directions in response to the modernist attitude of rational planning after its proclamation as the capital city of the Turkish Republic. During the process of modernization, along with the development of the nation-state, the traditional parts of the city were neglected in favor of the newly developed areas. The aim was to make the city the symbol of modern Turkey, which would be reflected in contemporary institutions, housing provision, and lifestyles developed through successive planning efforts. The result is a dual character reflected in the modern and traditional sections in the urban macroform strengthened by different living standards and lifestyles.

The Citadel is now the only area that portrays Ankara's historic and traditional past and the current attitude of creating an image for Ankara has led to efforts to restore and rehabilitate the older fabric. This was a reflection of the growing concern for the preservation of historic districts in older parts of cities. The ideology of a design competition held in 1987 for the rehabilitation of the Citadel and the proposal of the winning team reflect general tendencies throughout the world: it was proposed to renovate the old mansions in the area and to convert them into upscale restaurants and bars for well-off residents and visitors, while the more modest houses were to be turned into tourist accommodation. Although this appears to be a way of getting history and tradition back into the city, it represents the standardization attitude of using the process to attract an audience to this spectacle (Fainstein and Gladstone, 1999; Fainstein and Judd, 1999; Judd, 1999). Since the late 1980s, the physical interventions made in parallel with newly invented functions within the Citadel have changed the identity of this area, transforming it from a modest neighborhood to one with increasing commercial activity. Consequently, the area has become the focus of a unique relationship between low-income residents and visitors, each becoming the target of curiosity and object of observation for the other (Cohen, 1979; 1984; Urry, 1990). It can be stated that the dual character of the city is again reflected in the patterns of interaction between these two groups and in the ways their practices collide, overlap, and coexist in time and space.

The Ankara Citadel, which from a distance seems to be another case of a 'revitalized historic urban area', when studied closely conveys messages with a multitude of meanings. Only if it is viewed from different angles and its story discussed within various contexts can the layers by unfolded and the experiences become sensible. Therefore, the discussion should be made considering the many and sometimes conflicting aspects of the proposed scenario for this area and the transformation that is being experienced at present. In the following section, the particular experience of Ankara will be summarized with respect to its changing role, especially in the national context. This summary aims to identify the context of our case study and show how separate dynamics interact to bring about particular manifestations on 
urban space. The third part consists of a case study on the Ankara Citadel, which presents information about the condition of the physical stock, the property market, and the actors involved. The final section is a comprehensive evaluation of the results of the case study, structured around three main arguments. First, it is necessary to discuss whether there is deterioration or improvement in the Citadel's spatial qualities, despite the primacy of the concern for the physicality of such historic areas. The second discussion is related to whether there is economic feasibility in terms of the distribution of both economic and noneconomic benefits to all citizens or only to various interest groups, which brings forward the question of public interest. And the third and perhaps more complicated question is the ethics and legitimacy of the process, the way this transformation is planned to be implemented and experienced both by the visited and visitors, winners and losers, and citizen rights. These three issues are not separate entities and the problems encountered in one of them affect the others directly or indirectly.

\section{Ankara: a modern urban image versus historic heritage}

Ankara, which used to be one of the main trade centers of Anatolia, has a long history, dating back to the 8 th century BC. Following the Byzantine and Seljukid reigns, during the Ottoman period, the Citadel and its surroundings made up the town center which housed commercial and residential uses. This was indicated by separate neighborhoods accommodating various religious groups, as well as inns for the tradesmen, built in the 15 th and 16 th centuries. However, the city experienced a sharp recession, losing the major sources of its economic base after the 1850s. Although the railroad construction at the end of the 19th century started an upward swing, it was not sufficient to revitalize Ankara's economy. In addition, the destruction of the great fire in 1917 contributed to the decline of the city. Consequently, in the early 1920s, Ankara was a small modest settlement consisting of houses within the Citadel and along the slopes surrounding it (Altaban, 1987).

The fate of Ankara started to change drastically in 1923 with its proclamation as the capital city of the Turkish Republic. The goal of bringing unity to different regions within the national territory was reflected in the choice of Ankara, which is located at the center of Anatolia. In establishing a nation-state and creating this consciousness, spatial organization strategies gained an important role: it was believed that urban areas were the 'seedbeds' for creating modern citizens, conscious of their rights and responsibilities. Therefore, the modern city gained an instrumental function in this transformation and the planned development of Ankara was expected to provide a model for other cities (Tekeli, 1998).

This new role necessitated, in addition to various other amenities, the provision of buildings to house the institutions of government and the rapidly growing population needed for the new service functions. There was an intense debate on where the city should be located; the concern was whether the modest condition of the existing physical stock was appropriate to undertake the 'mission' of representing the modernist ideals of the young republic. This was the challenge of the project competition for the development of Ankara. The winning project, enacted in 1932, was based on the general principle of locating the new city beside the old one, with the intention of accommodating the increasing population in new housing areas, without creating pressure on the old city (Conservation Project Competition of Ankara Citadel 1987). Although the significance of the Citadel was acknowledged in this plan, there was not much concern for its integration. Accordingly, the role found for the Citadel was a 'frozen' one: its magnificent view formed the backdrop for the new city (Nalbantoğlu, 1998). This attitude did not include an operational proposal for preservation because of 
conceptual ambivalence towards the remains of the past as opposed to the promoted image of a 'modern' city and this led to unintentional but unavoidable neglect of the urban heritage (figure 1).

In the following years, there was major population growth in Ankara, particularly through the migration of low-income people from the surrounding settlements, which made the plan obsolete in a couple of decades. The resulting increase in demand for low-income housing created pressure on areas around the traditional center, leading to the emergence of illegal housing areas on topographically unsuitable public lands (Şenyapıl1, 1985).

A second plan, enacted in 1957, was intended to regulate the further development of Ankara, but again no particular consideration was given to the integration of the traditional parts of the city. This plan also became obsolete because of the increases in housing density, especially in central locations, owing to a legal change enabling flat ownership after the 1950s. In fact, the prevalent ideology at the time promoted living in apartment buildings as a symbol of a modern way of life. Buildings in this period were pulled down and reconstructed, reducing their useable lives to fifteen years (Altaban, 1998).

A third plan of 1982 was characterized by the enhanced importance given to planned development and central authority. This was based on a comprehensive planning approach, reflected in large-scale, metropolitan-wide, technologically rational, and efficient urban plans, prepared by the Metropolitan Planning Bureaus founded in major cities. This third plan for Ankara emphasized the decentralization of housing along the major transportation corridors on the western and southern axes, creating a new business center away from the traditional one. Thus, the identity of the Citadel and its vicinity gradually transformed into an area of traditional production and trade (Akçura, 1985) (figure 2).

After the 1980s there was a major change in the institutional planning setup with the transfer of planning responsibility to greater city municipalities. In addition, small local municipalities were given the right to make development plans independently.

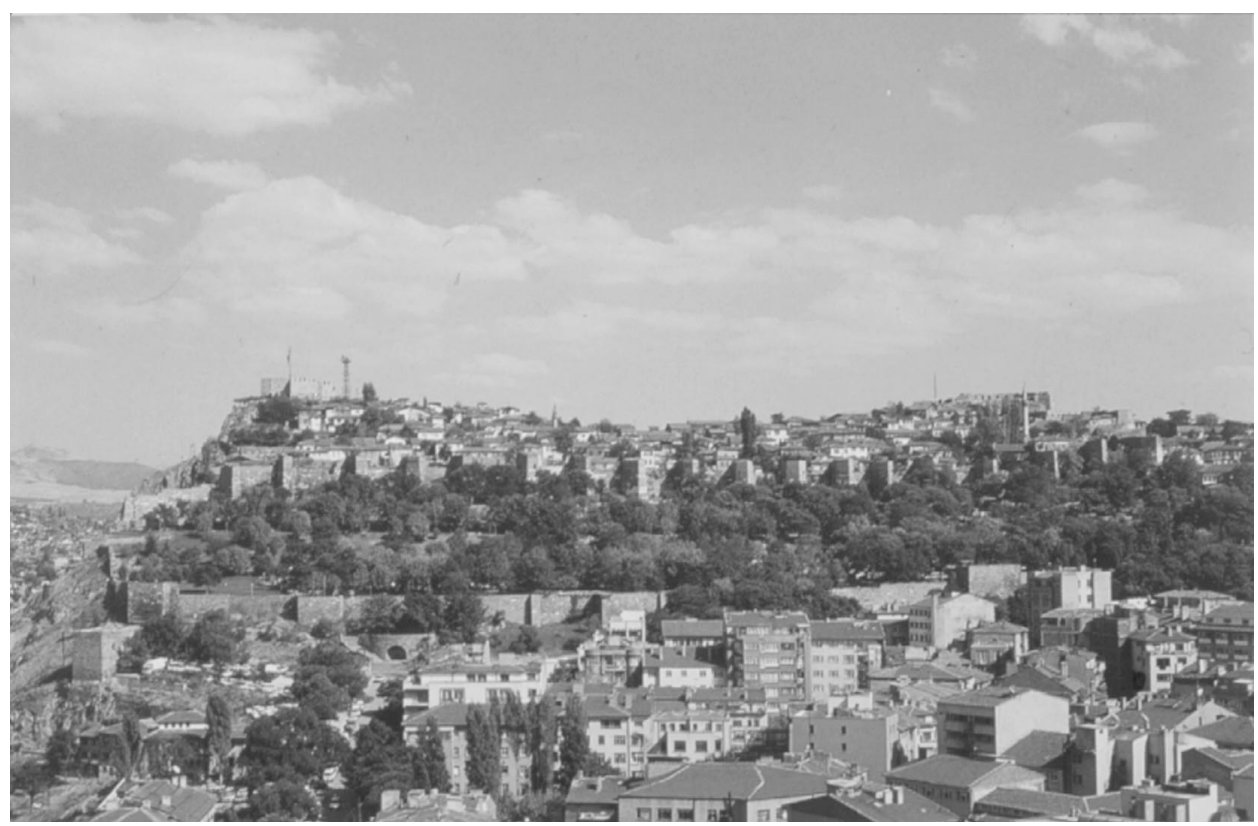

Figure 1. Ankara Citadel as the backdrop for the 'modern city'. 
These changes have led to a chaotic state in which institutions have various and sometimes overlapping responsibilities. During this period a new concern became pronounced, related to the preservation of traditional areas and their integration with the rest of the city. Until the 1980s the preservation of heritage was based on laws from the Ottoman period which concentrated on single monumental buildings. Only with the enactment of Legislation for the Conservation of Cultural and Natural Properties in 1983 was the consciousness of preserving a historic area as a whole, together with all its building stock, street pattern, and open areas, voiced. However, despite this consciousness, the preservation plans of historic areas were considered separately without being included in urban development plans (Aksoylu, 2000; Kangal, 1999; Madran and Ozgonul, 1984).

As the above summary indicates, the approach to the traditional center together with Ankara Citadel since the early 1920s has been ambiguous. Although Ankara's

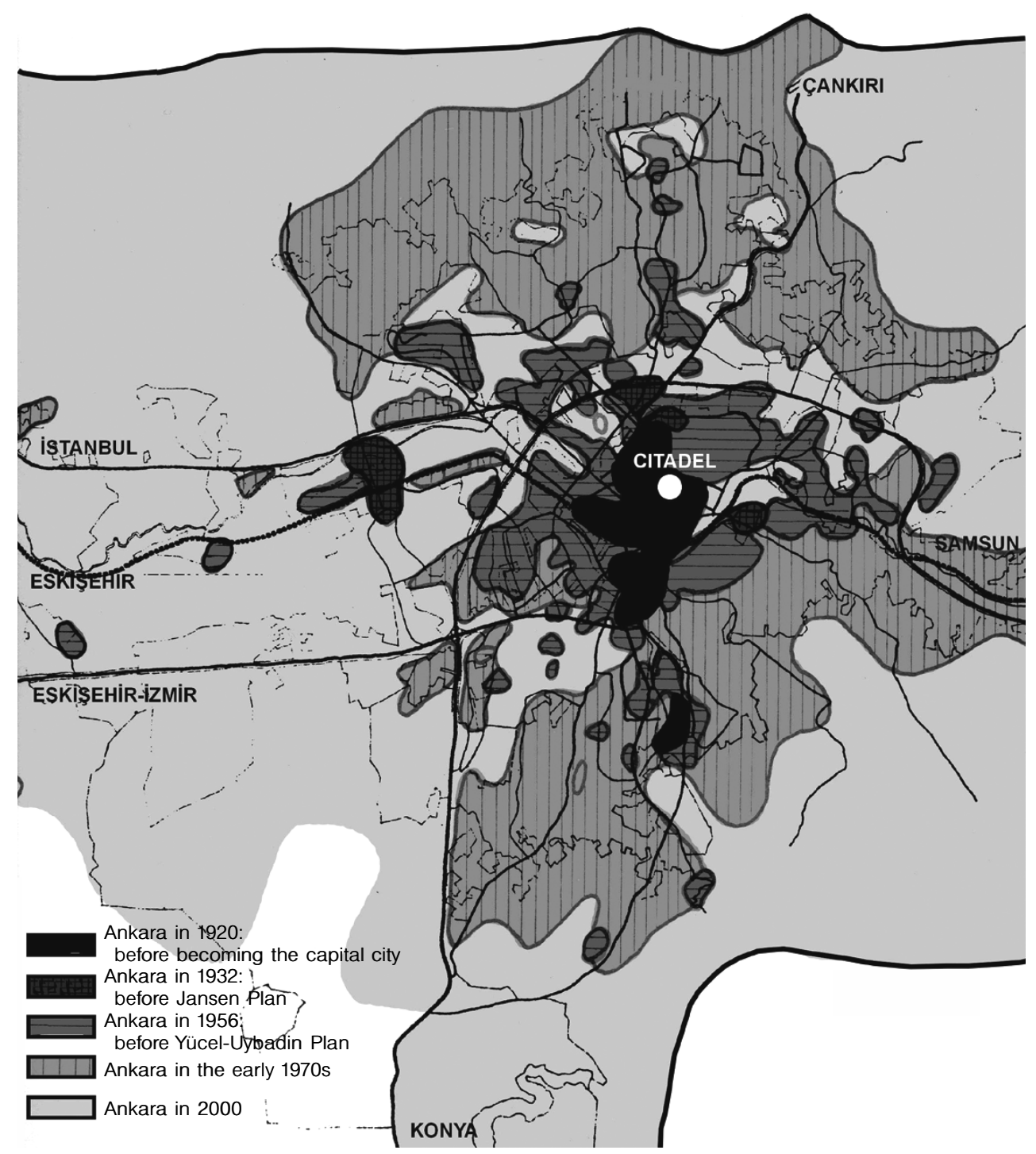

Figure 2. The development of Ankara since the 1920s and the location of the Citadel. 
development started from the Citadel area, during all the successive plan periods, housing development and major urban functions were directed away from that area, reducing its importance as a city center. The planning practice that attempted to rationalize the urbanization process assumed 'neat' areas; therefore, the localities of the past that house 'traditional' daily practices did not fit the sterile settings that would be manipulated according to the scenarios of the republic. As a result, within the zoning pattern of modernist planning, the Citadel and its surroundings were trapped between the twin pressures of land speculation and legal restrictions on construction and development. Consequently, the physical qualities of the historic environment, which were supposed to be preserved, were instead lost and the area has gradually turned into a site of urban decay.

At present, the Citadel is located within the crowded and disorganized old city center, which houses various functions ranging from small workshops, commercial units of various types, a major railway station, hospitals, museums, low-cost hotels, and housing. Transportation and parking are big problems and the area is surrounded by low-income squatter housing. Markets for traditional crafts and various local products give the area an almost rural character. There are still a number of historic inns from Ottoman times in the vicinity, and the Citadel as a whole was designated as a site of historic significance in the 1980s. The area has a tight network of narrow streets opening up to the main street and is densely built. Except for a number of old and strictly preserved houses, the building stock consists of mostly modest residential buildings. The locational advantage of being close to job opportunities, especially for unskilled labor, and to marketplaces has given the neighborhood a special appeal as a low-income housing area. In addition, during the last fifteen years, the area has experienced some changes: properties have been turned into restaurants, mostly catering for tourists and higher income residents of the city. A number of antique stores, carpet stores, and souvenir shops have also opened, with the hope that the tourists who visit the nearby Museum of Anatolian Civilizations would also come to the neighborhood (Ulusoy, 1998a; Ulusoy and Erendil, 1999).

In 1987 the local municipality, in collaboration with the Ministry of Culture and Tourism, announced a design competition for the conservation of Ankara Citadel. The objective of the competition was announced as "finding comprehensive solutions for social and physical problems of the Citadel" which would be economically feasible and implementable in terms of conservation, rehabilitation, and renewal (Conservation Project Competition of Ankara Citadel 1987, page 10). Preserving the historic and cultural values and the traditional setup, balancing this with development, and integrating the area with the rest of the city were the challenges to be tackled (Koç, 1992).

The result of the competition was announced in 1988. The aim of integrating the Citadel with the rest of the city was interpreted by the winning team as the complete transformation of the area into a tourist site. This means a major clearance of unsound buildings, pulling down the illegal additions, and changing the functions of buildings into restaurants, bars, art galleries, antique shops in the outer Citadel and mostly tourist accommodation in the inner Citadel. It is apparent that the decision on such a transformation has not been made as a result of a careful analysis of everyday practices and different dynamics in the area or of the potentialities of the existing building stock. It has mainly been developed on the standard attitude of changing a historic place into a tourist attraction area by creating a stage-like atmosphere tailored for new tourist interests (Boyer, 1992).

Because of disagreements among the members of the winning team, the contract could not be signed until 1990. Currently, the final version of the project is still being studied by various related institutions, leading to legal ambiguity for interventions. 
Because of this ambiguity, the area has experienced substantial changes that invalidate at least some of the premises upon which the project was based; most of the conversions during this time were done without permission and their court cases still continue.

Since the 1920s the Citadel has been neglected in an attempt to create a modern urban image for the new republic according to urban planning principles adopted from Western models. A similar attitude can currently be observed in the intention to transform a historic area according to some standard model of promoting an image for the city by manufacturing its forgotten heritage. This seems to be another kind of neglect; this time of the transformation potentialities of the social, cultural, and physical structures established over time and the meaning and image of the Citadel prevalent among the citizens of Ankara. This indifference is reflected in the form of top-down measures shaped according to the short-term interests of powerful and able actors involved in this process, which leads to undesirable consequences both in terms of the preservation of the urban heritage and of the public interest of all citizens.

\section{Case study}

\subsection{Methodology and sources of data}

We argue that any urban study must consider the complexity of the dynamics manifested in a particular area. Therefore, there is a need to develop analytical tools to represent this complexity without losing sensitivity. Especially in rapidly changing areas, critical realism creates opportunities to uncover the interacting structures and their hierarchical powers in directing change in different time-space contexts (Erendil, 1998; 2000). The use of both extensive and intensive methods helps us to cross check information produced from various sources and to enrich interpretation (Sayer, 1984).

In this study, the first type of data is based on the official records of title deeds which give information about real-estate between 1932 (when properties were first registered after the creation of the republic) and 1999. Therefore, it became possible to categorize the market transactions in different periods of time, and these can be identified with important changes affecting the city.

The second type of data is obtained through questionnaires, which were distributed to about $50 \%$ of the households in the area. The analysis of the questionnaires gives information about residents in terms of their origin, income levels, tenure structure, their reasons for locating in the Citadel, duration of stay, etc. These give hints about the limitations or possibilities in the process of transformation.

The third type of data came from intensive interviews with major actors with different interests and attitudes to the Citadel. These people were chosen from among long-term inhabitants who have themselves experienced the transformation within the Citadel in daily life, newcomers, the owners of new commercial establishments, present and previous representatives, and responsible civil servants in the local municipality, as well as with preservation experts.

\subsection{Condition of the physical stock}

The physical characteristics of a settlement and the condition of the building stock are important factors in determining what an area can afford to accommodate. Therefore, it is crucial to investigate the present characteristics in order to assess the feasibility of the scenarios that propose a complete transformation of the area into a tourist attraction. When the current state of the Citadel is studied, it can be observed that commercial gentrification has occurred. Generally houses with distinctive characteristics or those big enough to accommodate functions other than housing are being 
renovated and turned into restaurants, bars, and shops serving especially foreign tourists (figure 3).

The property data show that there are 280 plots of different sizes within the Citadel, $93.3 \%$ of which are privately owned. The houses located on those plots have either one, two, or three stories. When the current land use of the area is studied, it can be seen that there has been a substantial functional shift in the outer Citadel while the inner Citadel retains its predominantly residential character (table 1).

The original settlement structure of the Citadel has eroded over the years because illegal extensions and infill structures, changing the relationship between the street, the house, and the plot. In other words, the house-street-neighborhood relationship, which reflects the hierarchy of private, semiprivate, and public spaces, has been transformed

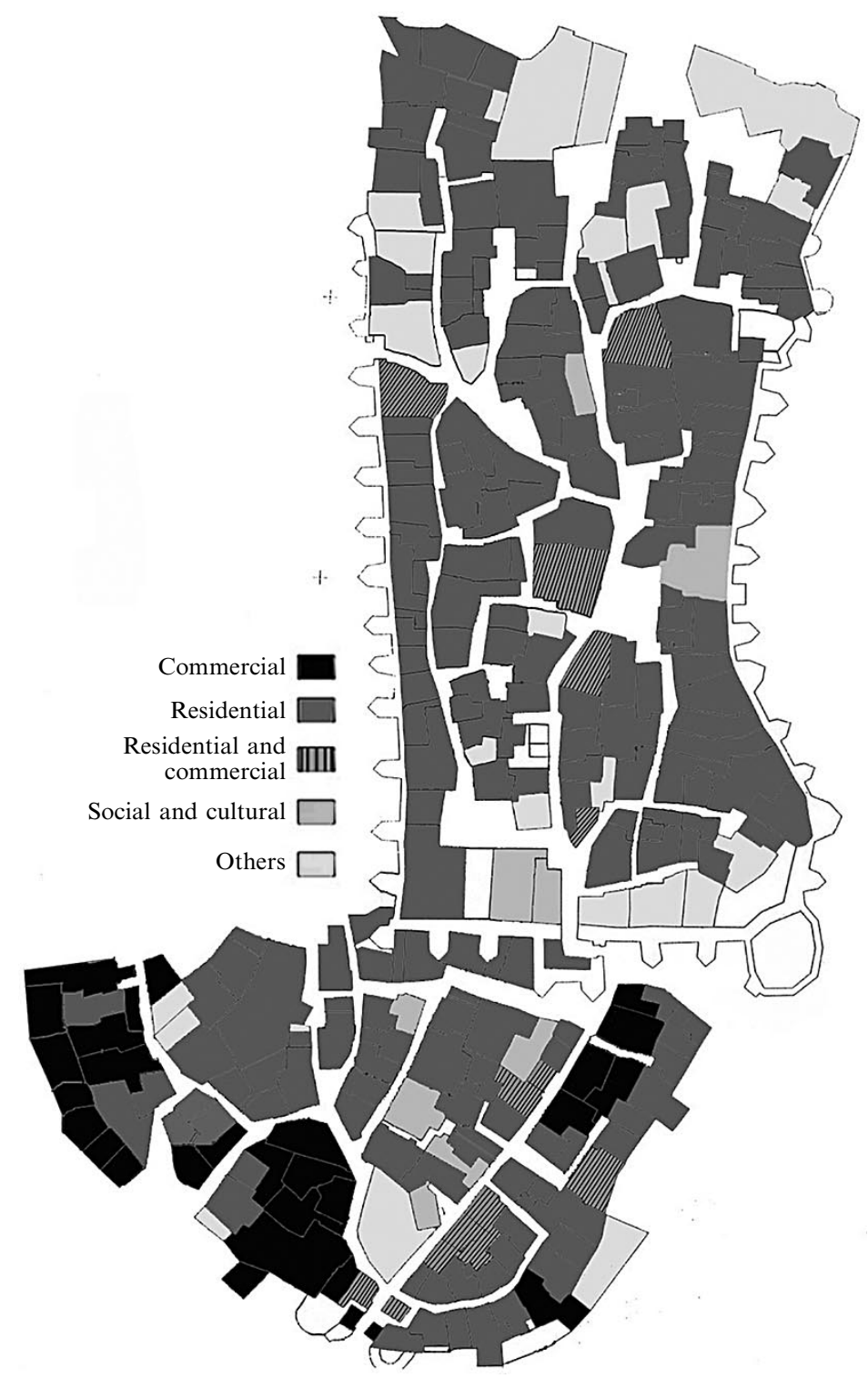

Figure 3. Functional distribution in the Ankara Citadel in 2000. 
because the extensions or infills have defined new types of relationships between the masses within the plot and between neighboring plots. As for housing, it was observed that for economic reasons most of the houses have been subdivided to accommodate more than one household. According to the findings of our questionnaires, over $50 \%$ of the houses have been subdivided to achieve more than one housing unit. Although the number of household members varies, occupation of a two-room unit is a general trend in the area, reflecting serious overcrowding. The subdivision into separate housing units has necessitated the addition of various amenities, such as a kitchen and toilet for each unit, which has led to the use of courtyards and also the halls within houses. Naturally, architectural elements, such as doors, windows, niches, and cooking spaces have also been affected because of the requirements of new uses. In general, it can be claimed that such extensions and subdivisions have led to a substantial loss in the distinctive characteristics of housing in the area (Asatekin, 1999).

\subsection{Property market}

The transaction data show that plots have changed hands continuously in the property market since the 1950s. As mentioned above, owners who could afford to buy properties in newly developing housing districts moved out over time as the Citadel lost its appeal as a prestigious housing alternative. They either sold or rented out their houses by subdividing them into separate units; there are also houses which have been left to decay in the area. This trend is related to changing housing preferences and the supply of 'modern' housing in newly developed parts of the city. On the other hand, this also stems from inadequate public support for renovation and restoration, which is quite costly, as well as from long years of hesitation in action because of limited financial resources and the lack of consciousness for preservation both on the side of governments and the general public.

When the transaction data are studied in ten-year periods, it can be seen that, in all periods after 1950, the rate of sales was high. In other words, in all periods, about one fifth or one sixth of the properties changed hands (table 2). The highest rate of

Table 1. Functional distribution of properties in outer and inner Citadel.

\begin{tabular}{lll}
\hline Functional distribution & $\begin{array}{l}\text { Outer Citadel } \\
(\%)\end{array}$ & $\begin{array}{l}\text { Inner Citadel } \\
(\%)\end{array}$
\end{tabular}

\section{Housing}

Commercial: cafes and restaurants

Commercial: shops ${ }^{\text {a }}$

Cultural facilities

Religious facilities

Vacant plot

Other uses

Total

$\begin{array}{rr}57.5 & 83.2 \\ 15.9 & \\ 16.8 & 3.0 \\ 2.7 & \\ 1.8 & 1.8 \\ 3.5 & 10.2 \\ 1.8 & 1.8 \\ 100 & 100\end{array}$

a These are generally shops with housing on the second floor.

Table 2. Distribution of property sales in ten-year periods.

\begin{tabular}{lllllll}
\hline $1930-49$ & $1950-59$ & $1960-69$ & $1970-79$ & $1980-89$ & $1990-99$ & Total \\
\hline $16.8 \%$ a & $19.4 \%$ & $18.4 \%$ & $15.7 \%$ & $16.9 \%$ & $12.7 \%$ & $100 \%$
\end{tabular}

a This ratio covers a twenty-year period. 
sales was seen between 1950 and 1970 when the area rapidly lost its prestige for middle-income and high-income people, especially because of squatter developments in the vicinity. As a result, the Citadel became affordable for low-income households, leading to a transformation in the socioeconomic character of the area. However, during the 1990s, there was a decrease in the rate of sales. This stagnation may be caused by a variety of reasons, which can be explained in terms of the characteristics of the properties and the interests of the buyers in the area. The big mansions with the potential to be converted into commercial uses have been attractive to entrepreneurs since the 1980s; however, the small, modest buildings which have lost their original characteristics because of subdivisions and infills have become attractive for lowincome people owing to their low price. Thus, the decrease in sales may indicate that the owners of the first type of buildings are unwilling to sell their properties because of expectations of higher rent related to developments in the Citadel.

There is no mortgage system in Turkey to encourage the purchase of property by extending the repayment of loans over a long duration. Since the 1980s, the disposable income, and thus the capability of saving, of middle-income and low-income people has gradually decreased in Turkey. This has been reflected in lower sales for the second type of buildings in the area especially after 1990. Another factor for the decrease in sales may be the high cost of renovation and repair of the decaying housing stock, investments which cannot be paid off in the short run.

Transaction records indicate that outsiders rather than one of the shareholders have bought the majority of plots $(74.6 \%)$. In addition, most of the sales have been realized with market incentives, as opposed to those related to inheritance problems. All these figures reflect a continuous demand for the area and a substantial shift in population throughout the years, supporting the questionnaire findings about present inhabitants. This shift is related to the increase in the number of lower income residents, leading to a change in the social structure, the type of community relationships, and the way the housing stock is used.

\subsection{Actors}

Our research shows that the current state of the Citadel reflects the struggle between various actors with conflicting interests. These include the following groups: the local municipality; the winning team of the project competition; various preservation groups and institutions; people who want to return the Citadel to its 'previous' condition with nostalgic overtones; the owners and managers of the new establishments, who want to maximize their profits; and the residents, both introverted old-timers and insecure newcomers.

As mentioned before, there has been a continuous conflict between the winning team of the competition and the local municipality, both of whom are trying to control the implementation process. Because of this conflict there has been a legal ambiguity in practice since the 1980s, and the transformations experienced at present could not be properly monitored. This has led to controversies in preservation practice, resulting in conflicts with the preservation officials.

In addition to these professional or institutional groups, there are other actors who are directly involved in the changes in the Citadel. One of these, a neighborhood association founded by some of the neighborhood's old-timers, emphasizes the preservation of the historic heritage and community characteristics, opposing the increasing presence of commercial uses in the area. On the other hand, because of inadequate financial resources and lack of support from other resident groups, they are not effective in making a change. Obviously, there is a serious conflict between this group and the owners and managers of the new commercial establishments. 
The largest group in the area is still the residents, mostly tenants $(64.2 \%)$, who have moved to the Citadel over the last fifteen years $(80.3 \%)$. Although there has been a significant functional transformation particularly in the outer Citadel since 1985, it has not led to a dislocation of inhabitants, as has been the case in many examples of residential gentrification (Beauregard, 1990; Jones and Varley, 1999; Lyons, 1996; Smith, 1986). On the contrary, over the years, the Citadel has turned into an area of low-income housing and this characteristic has been almost established at present because of the area's locational advantages and the affordability of its housing stock for this group.

When income levels are studied, the majority of the households $(69.7 \%)$ are in the low-income category. There is no significant difference between owners and tenants in this respect. Households who can be accepted as middle-income are either those with more than one wage earner, or the owners of the small establishments nearby. Related to the poor conditions of the housing stock and income levels, rents are also low (51.4\% of the monthly rents ranged between US $\$ 40$ and $\$ 70$ in November 1999) compared with rents in other low-income residential areas.

In general, it can be seen that the majority of the inhabitants are migrants who have settled in Ankara and the Citadel in different time periods. When the duration of stay in the Citadel is considered, those who have been living in the Citadel for more than twenty years constitute only $19.7 \%$ of the total population. On the other hand, $69.1 \%$ of the inhabitants have moved to the Citadel in the last fifteen years $(48 \%$ in last ten years), who we name 'newcomers'. These figures show a major population turnover through the years, leading to a change in the social structure of the area. This observation is also supported by people who have been living there for a long time. The 'old-timers' claim that the area used to be known for close neighborhood relations and a strong sense of solidarity among the residents. However, the moving out of owners after the 1950s, coupled with the increase in single tenants, resulted in a change in the identity of the area. It is even said that in the 1960s and 1970s the adjoining park and certain parts of the neighborhood were perceived as dangerous, which made the area an undesirable neighborhood for families. Therefore, those who had the choice of moving out left the area in time by selling their houses or subdividing them to accommodate a rapidly changing population. After the 1980s there was another major change in the population structure. The questionnaires show that, especially after 1985, the concentration of people from a city in eastern Anatolia, Malatya, increased, constituting about $40 \%$ of all settlers. This shows the importance of informal relationships among newcomers in deciding to settle in an area. Another factor which is influential in this agglomeration is the presence of workplaces in the traditional center within walking distance and a high number of workplaces in various sectors owned by people from the same city. At present, the area can be identified as a low-income neighborhood mainly inhabited by people from Malatya.

When the main reasons for preferring to stay in the Citadel are analyzed, owners and tenants seem to have different priorities. Of the owners $66.7 \%$ give financial factors as their main reason to stay, and this was also reflected in the pessimism and feeling of being trapped that we observed during our informal interviews with residents. This is particularly true for two-person households who have been living in the citadel for over twenty years. These are mainly retired people whose children have moved out to other housing districts in Ankara. On the other hand, a large majority of the tenants $(79.6 \%)$ state the cheapness of housing and nearness to work as the basis of their preference, which indicates an act of choice as opposed to passive acceptance. These households mostly consist of nuclear families, which may indicate an intention to stay in the Citadel. There does not seem to be serious friction among inhabitants because of their 
similar income levels, living standards, and the fate of sharing the same location and facing the same problems. Yet, because most of the inhabitants are renters who have moved to the area during the last ten years, there is a lack of communication between the old-timers and newcomers which undermines the opportunity of acting together for their shared interests. In addition, the sense of belonging to the area seems to be weak owing to many factors. The ambiguity about future developments in the area and the lack of information about their rights in terms of repair and renovation, coupled with the anticipation that there will be interventions from above, all contribute to this state.

\section{Discussion and concluding remarks}

Now that we have identified the context of transformation being experienced and the current conditions in the Citadel, it is necessary to discuss the appropriateness of its future prospects. These are exemplified in the proposed scenario of the design competition in terms of its attitude to the preservation of the physical stock, economic feasibility within the context of Ankara, and the ethics and legitimacy of such an approach. In the following sections, we will attempt to discuss these issues related to the findings of our research.

The current scenario developed for the Citadel is based on the consumption of the facilities and services in the area by well-to-do outsiders, either locals or foreign tourists. Because these groups visit the place occasionally for a short duration of time, their involvement in the area is limited to 'just looking' (Boyer, 1992). As noted above, the scenario of the winning project is based on changing the whole area into a museum, in which only the 'able' actors can have a place. In other words, as the buildings in the outer Citadel are expected to turn mostly into leisure, entertainment, and cultural facilities, the inner Citadel is expected to accommodate family-run tourist accommodation as well as some arts and crafts centers. All these activities are based on income generation for some actors, either entrepreneurs or property owners in the area; however, when the existing and potential users are considered, it is apparent that all these changes will serve the demands of well-to-do residents of the city and foreign tourists. The role found for its inhabitants, who will be able to stay in the area until a more or less complete transformation is achieved, is to serve the audience by placing their lives on stage, thus being both part of the play and serving the 'refreshments'. The revitalization project has not yet started to be implemented because of the conflicts between the winning team and the local authority. The fifteen-year delay in implementation has created an ambiguity, which resulted in individual and partial attempts of local actors in the last decade, particularly in the outer Citadel. Although these developments seem to be similar to the proposed scenario, the control mechanisms to govern the changes are lacking, leading to a choice situation both legally and physically.

Our findings enable us to discuss the problem of preservation practice and the way the building stock and land use are being transformed at present; in other words, whether there is physical deterioration or improvement in this respect. It can be observed that individual and partial attempts to restore the buildings to house new functions do not conform to professional and scholarly standards, although almost all the proposals, including the winning project, are made with the rhetoric of restoration, behind the 'politically correct' shield of conservation. Who should do the restoration, how it should be approached, what level of intervention is acceptable, to what extent the restoration conforms to the 'original' condition of the buildings are the questions raised. Hence, the discussion turns into one of professional practice, which does not pay attention to the particularities of the area. It is also interesting that most of the research about the Citadel deals with the historic properties, and, thus, the physicality of the heritage becomes the most important aspect of the area. 
This emphasis, unintentionally, disguises the complexity of issues behind the label of conservation, such as the coherence in the legal framework, the clarity of the procedures to be followed, fair access to financial resources, and the availability of information and know-how in these terms.

The emphasis on the physicality of heritage disregards the importance of local actors and their capabilities to affect the direction of transformation (Ulusoy, 1993; 1998b). In fact, they can have an instrumental role in promoting change either in a direction that is beneficial for different groups in the city, or favoring short-term interests that may lead to the corruption of the physical stock and to practices that are unacceptable in terms of proper restoration. At present, two major groups with different types of interests are involved in the changes being experienced in the Citadel. The first group consists of inhabitants, both renters and owners, whose preference to stay in the Citadel is based on the job opportunities nearby and the affordability of its housing. The second group, on the other hand, are the owners of various types of establishments for whom the Citadel has commercial connotations; therefore, their priorities are renovating the buildings and the surrounding areas so as to create attractions for tourists and the 'consumers' of the Citadel. Thus, none of these major actors has a concern for the historic significance and use of the area while preserving it. The weakness in the legal basis of enforcing plan decisions creates ambiguity, which enables people to act as they will. The consequence is a superficial concern for preservation through inappropriate and illegal interventions to the buildings. This is the reason why there is a continuous conflict between these major actors and the institutions in charge of the area's preservation. It can be claimed that top-down models for transformation, which do not consider the capabilities and hierarchical powers of actors involved, are likely to lead to unintended results.

Because the area is identified with historic inns from the Ottoman period, its distinctive settlement pattern, and the nearby museum of Anatolian Civilizations, it is accepted that it has the potential to attract tourists. However, in terms of economic feasibility, it can be claimed that Ankara is not an attractive destination for a long stay compared with other tourist sites in Turkey. When the evolution of Ankara is considered, it can be seen that it is spatially organized to house the necessary functions of a capital city. The institutions and monuments of the modern state had for decades been its symbols and visitors were taken to such places to appreciate the success of the modern republic. The Citadel had no role in this play until the recognition of the recent interest in historic heritage and daily practices that make the place unique. It was discovered that this rather new interest could also generate income, if marketed correctly. At present, Turkish or foreign visitors come to the city for various business transactions, conferences, and meetings, related to the presence of governmental institutions, universities, and civic organizations. Although there are hotels of various standards in the newly developed parts of the city, the Citadel area may still be an option for accommodating or serving those visitors. In fact, there is a newly opened boutique hotel within the Citadel, which has become attractive for the ambassadorial visitors. In many cases it can be observed that there is a demand to stay in the historic parts of cities, as a new type of experience. However, the customers of such places are unlikely to be able to differentiate a consciously preserved historic site from a stage-like setting. Therefore, it is necessary to discuss this issue in terms of the ethics of preservation, the quality of what is being supplied both to the citizens and to the visitors, and the consequences of such transformations in historic contexts.

It is now widely discussed and accepted that, although there are as many stories as there are cities, the recent trend of upgrading the image through manufacturing identities for localities ends up with a variety of cases which in fact represent the 
same standardization process. Thus, urban regeneration, downtown revitalization, gentrification of inner-city neighborhoods, and the redevelopment of obsolete industrial sites all serve inherently the same purposes under various disguises: turning places into commodities. In this attempt to market places, the task is not only promoting and advertising, but also creating and adapting the places so that they are more desirable to the market (Fainstein and Judd, 1999). This is particularly the case when dealing with historic sites, where the main goals are both to construct new images to replace the old ones and to recreate places that are in harmony with the preferred images (Holcomb, 1993; Sadler, 1993). Places may have multiple meanings but in recent attempts to create new urban images and 'city myths', only one image is promoted, reducing the multiplicity of identities of localities (Massey, quoted in Goodwin, 1993, page 149). The culture of a place is tightly intertwined with the history of that place and of the peoples who have been living there. Hence, the manipulation of culture in the selling of places tends also to be manipulation of history, selectively picking items and stories to be presented without the responsibility of representing the tensions and conflicts that are inseparable from that history (Philo and Kearns, 1993). Such a 'theming' (Sorkin, 1992) of history may turn into a 'heritage industry' producing 'fantasies of a past that never was'. In this process, the in-depth comprehension of history is lost, because what is provided is more like a 'costume drama' and a 'reenactment' of history (Hewison, 1987). The kind of past we choose to preserve and for what purposes - in other words, what is meant by 'authentic'-depends on cultural, political, and ideological standing in a particular context, which is a highly contested and controversial issue. This is hardly questioned in current practice and, in most cases, the standard attitude of transforming a place according to the demands of an average tourist is adopted. The irony in this process is that attempts to emphasize the unique qualities of a place end up generating sameness and blandness, because a very similar vocabulary is used in the appearance of those places. The signs and symbols used in this vocabulary are charged with codified ideologies that are internalized in the social practice of everyday life. These codes are disseminated through media and advertising throughout the world and become useful tools to meet the expectations of the universal tourist industry (Gottdiener, 1995; Urry, 1995). This is related to the civic leaders' and tourism entrepreneurs' conformity to previously used models which have proved to be successful in attracting tourists (Fainstein and Judd, 1999).

It should be noted that, as opposed to this overregulated form of tourism, there may be people who search for more 'real' experiences that are different from those encountered customarily (MacCannell, 1976). This expectation may entail observing the lives of others that are not immediately evident to outsiders, thus discovering different parts of cities and ordinary practices themselves instead of strolling in 'tourist bubbles' (Judd, 1999) or being directed towards particular nodes in cities by tourist guides. Actually, the Citadel has the potential for such a less organized and more individualized form of tourism. What is attractive for the visitors to the Citadel is the possibility of witnessing people's daily practices. One of the main reasons for the interest in the area at present is that it offers a curious intersection between the traditional, villagelike lifestyles of low-income residents, and the new restaurants, bars, and antique shops whose users are from the 'other' world. However, at present, package tourist organizations do not provide opportunities for such individualized experiences; tourists come to Ankara on their way to more popular tourist sites in the region, such as Cappadocia. This tour involves visiting the Museum of Anatolian Civilizations nearby and, after a short stroll through the streets, having lunch or dinner in one of the restaurants in the Citadel. This standard attitude, coupled with the directives of the proposed project, has created pressure on the present physical and social structure, 
enforcing overregulation, which would transform the area into a stage-like setting over time. Therefore, the whole area is prone to be the object of 'tourist gaze', similar to what is called "a postmodern museum culture in which almost anything can become an object of curiosity for visitors" (Urry, 1990, page 107).

This trend is most likely to destroy the 'authenticity' of layer seen both in the social structure and in the building stock in the long run. As an alternative to a 'staged atmosphere', some measures to sustain this quality need to be suggested. Preserving the identity of the area can be realized by encouraging the accommodation of some new groups of people who will help to defend sustaining the livelihood of a real-life environment as opposed to the leisure/consumption atmosphere created by the growing presence of commercial establishments for visitors. We believe that proposals for the Citadel should consider the priorities and capabilities of the current inhabitants as a whole. At present, there are basically two groups: owners of commercial establishments and residents. Residents become involuntarily an important part of this process, because of their weakness in defending their rights and privacy. The present residents, both renters and owners, have almost no information on the future prospects for the area. They are faced only with the changes, which usually cause troubles in their daily lives because of the intrusion of people flocking through the streets and the noise from restaurants and bars during the night. Because of the threat of top-down measures, such as expropriation or clearance, residents feel insecure in defending their rights and in expressing their complaints. They prefer to remain indifferent to the changes by involuntarily normalizing the process through becoming a part of the stage. Furthermore, because of the low incomes in the area, people are eager to work in new establishments or to sell handicraft items to tourists, however small their share is in the total number of inhabitants. Their indifference also stems from the possibility of benefiting from this opportunity.

Neither of these groups can be expected to give priority to preservation when it conflicts with their short-term interests. Sustaining the area's uniqueness necessitates people who are, intellectually and economically, willing to and capable of preserving its heritage. Hence, we suggest creating the conditions for attracting different groups of people who would enrich the social structure and balance the dominance of the two major groups at present. When the social and physical conditions in the Citadel are considered, it seems to be suitable for some segments of the middle class who would deliberately choose to live in this environment. These groups may include intellectuals such as artists, academicians, or students who would also become role models both in the conservation of the building stock and in establishing social cohesion among the residents to defend their shared interests. One of these interests, which is not defined at present, is related to the consciousness of living in an area of high historic significance. The perception that this heritage belongs both to the present citizens as well as to future generations should be established among the residents of the area. On the other hand, this consciousness can be effective only by enabling people economically and assisting them in their efforts at restoration and rehabilitation. Empowering the residents through subsidies and participatory programs not only leads to a heightened level of consciousness and a strengthened sense of belonging among them, but also to viable transformation of the area in which the built heritage is preserved voluntarily, not through enforcements and within restrictions.

Proposing a mixed physical and social structure for a less-regulated tourism raises the question of the separation between the public and private domains of life and the definition of boundaries between them. If a 'real-life' experience is accepted as desirable, then the outsiders to the area will not have the right to act only according to their own interests. Therefore, it should be expected that the relationships would develop 
regarding the priorities of all parties. In a stage-like atmosphere prepared for tourists, it is most likely that people feel themselves to be 'customers' rather than 'visitors'; therefore, the type of behavior develops on this rationale. It is necessary to comprehend that the relationship between the residents of the area and the 'visitors' would acknowledge the boundaries between equal partners; in other words, the respect for each other's rights. There should be a delicate balance between the visitors and the visited, which needs to be redefined at every stage, in accordance with the transformations experienced. The consciousness of consumer rights which is continuously being strengthened in this world of consumption should be balanced with the consciousness of being a 'visitor' whose limits are defined in particular ways among different people in a variety of contexts. This type of consciousness is the only chance for forming real-life relations, if desired, and will be a solution for the awkward position of a tourist, who wants to experience 'authenticity'.

Acknowledgements. This article is based on a study supported through Bilkent University's Faculty Development Research Grant Program. We also thank our colleagues Christopher Wilson for reading the final version of the manuscript, Murat Koçer, Ayşegül Tokol, and Kerem Yeşilkaya for helping us with the maps, as well as Türkan Erbay and Kamile Şanlı for data processing.

\section{References}

Akçura N, 1985, "Ulus - tarihi ticaret merkezi planlama çalışmaları kapsamında 'koruma' sorunlar1 - konut dokusu konusunda bazı görüşler" [Problems of restoration within the context of the planning of Ulus historic trade center - some views on residential pattern], in Ulus Tarihi Kent Merkezi Çevre Düzenleme Yarışması [Ulus historic city center environmental design competition] (Ankara Büyükşshir Belediyesi, Ankara) pp 52-58

Aksoylu S, 2000, "Eski kent dokularında koruma: koruma imar planlarının doku karakterine olumsuz etkileri" [Preservation of historic city fabric: the negative effects of preservation plans on the character of the urban fabric] Arredamento Mimarlık November, 117-121

Altaban Ö, 1987, "Kentte yapılaşmayı belirleyen süreçler" [Processes that determine construction in cities], in Ankara: 1985'den 2000'e (Ankara Büyükşehir Belediyesi, Ankara) pp 31 - 48

Altaban Ö, 1998, "Cumhuriyetin kent planlama politikaları ve Ankara deneyimi" [Urban planning policies of the Republic and the Ankara experience], in 75 Yllda Değişen Kent ve Mimarlk [ Changes in urban areas and architecture in 75 years] (Tarih Vakfı Yayınları, İstanbul) pp $41-64$

Asatekin G, 1999, "Ankara Kalesi’ndeki geleneksel konutlarda değişim”, [Changes in the traditional houses of the ankara Citadel], in Tarih Içinde Ankara II Sempozyumu Bildiriler Kitabı [ Ankara in history II symposium, book of proceedings] ODTÜ Mimarlık Fakültesi, Ankara, pp $203-235$

Beauregard R, 1990, "Trajectories of neighborhood change: the case of gentrification" Environment and Planning $A 22855-874$

Beauregard R, 1998, "Tourism and economic development policy", in The Economic Geography of the Tourist Industry Eds D Ioannides, K G Debbage (Routledge, London) pp 220-234

Boyer M C, 1992, "Cities for sale: merchandizing history at South Street Seaport", in Variations on a Theme Park Ed. M Sorkin (Hill and Wang, New York) pp 181-204

Cohen E, 1979, "A phenomenology of tourist experiences" Sociology 13 179-201

Cohen E, 1984, "The sociology of tourism: approaches, issues, and findings" Annual Reviews in Anthropology $10373-392$

Conservation Project Competition of Ankara Citadel 1987 (Altındağ Municipality, Ankara)

Erendil A, 1998 Using Critical Realist Approach in Geographical Research: An Attempt to Analyze the Transforming Nature of Production and Reproduction in Denizli unpublished PhD thesis, Department of City and Regional Planning, Middle East Technical University, Ankara

Erendil A, 2000, "Mit ve gerçeklik olarak Denizli-üretim ve işgücünün değişen yapısı: eleştirel kuram açısından bir değerlendirme" [Denizli as myth and reality - the changing structure of production and labor: an evaluation in terms of critical theory] Toplum ve Bilim 86 $72-117$

Fainstein S S, Gladstone D, 1999, "Evaluating urban tourism", in The Tourist City Eds D R Judd, S S Fainstein (Yale University Press, New Haven, CT) pp $21-34$

Fainstein S S, Judd D R, 1999, "Global forces, local strategies, and urban tourism", in The Tourist City Eds D R Judd, S S Fainstein (Yale University Press, New Haven, CT) pp 1 - 17 
Goodwin M, 1993, "The city as commodity: the contested spaces of urban development", in Selling Places: The City as Cultural Capital Past and Present Eds G Kearns, C Philo (Pergamon Press, Oxford) pp $145-162$

Gottdiener M, 1995 Postmodern Semiotics (Blackwell, Oxford)

Harvey D, 1987, "Flexible accumulation through urbanization: reflections on post-modernism in the American city" Antipode $19260-286$

Hewison R, 1987 The Heritage Industry (Methuen, London)

Holcomb B, 1993, "Revisioning place: de- and re-constructing the image of the industrial city", in Selling Places: The City as Cultural Capital Past and Present Eds G Kearns, C Philo (Pergamon Press, Oxford) pp 133-143

Jacobs J, 1961 The Death and Life of Great American Cities (Vintage Books, New York)

Jones G A, Varley A, 1999, "The reconquest of the historic centre: urban conservation and gentrification in Puebla, Mexico" Environment and Planning A 31 1547-1566

Judd D R, 1999, "Constructing the tourist bubble", in The Tourist City Eds D R Judd, S S Fainstein (Yale University Press, New Haven, CT) pp 35-53

Kangal M, 1999, "Kültürel ve doğal çevrenin korunmasında planlama, sorunlar, ve olanaklar" [Planning, problems and opportunities in the preservation of the cultural and natural environment], in Kent Planlama, Çevre Koruma Semineri 7-9 Ekin, İzmir (İller Bankası Genel Müdürlügü, Ankara)

Koç A R, 1992, "Ankara Kalesi ve Koruma İmar Planı uygulamaları" [The Ankara Citadel and the implementation of the preservation plan], in Koruyucu Kent Yenilemesi ve Yerel Yönetimler [Protective urban regeneration and local government] (Mimarlar Odası, Ankara) pp $37-40$

Lyons M, 1996, "Gentrification, socioeconomic change, and the geography of displacement" Journal of Urban Affairs 18(1) 39-62

MacCannell D, 1976 The Tourist: A New Theory of the Leisure Class (Schocken Books, New York)

Madran E, Ozgonul N, 1984, "Planlı Dönemde (1963 - 1981) tarihsel çevrenin korunması ve değerlendirilmesinde kamunun yaklaşımı" [The approach of the public realm in the conservation and utilization of the historic environment in the planned era (1963-1981)], in Türkiye Birinci Şehircilik Kongresi, 2. Kitap [First urbanization congress of Turkey, 2nd book] ODTÜ Mimarlık Fakültesi, Ankara, pp 283-294

Nalbantoğlu G B, 1998, "Silent interruptions: urban encounters with rural Turkey", in Rethinking Modernity and National Identity in Turkey Eds S Bozdoğan, R Kasaba (University of Washington Press, Seattle, WA) pp $192-211$

Philo C, Kearns G, 1993, "Culture, history, capital: a critical introduction to the selling of places", in Selling Places: The City as Cultural Capital Past and Present Eds G Kearns, C Philo (Pergamon Press, Oxford) pp $1-32$

Sadler D, 1993, "Place-marketing, competitive places and the construction of hegemony", in Selling Places: The City as Cultural Capital Past and Present Eds G Kearns, C Philo (Pergamon Press, Oxford) pp $175-192$

Sayer A, 1984 Methods in Social Science (Routledge, London)

Şenyapılı T, 1985 Ankara Kentinde Gecekondu Gelişimi [The development of squatters in Ankara] (Kent-Koop, Ankara)

Smith N, 1986, "Gentrification, the frontier, and the restructuring of urban space", in Gentrification of the City Eds N Smith, P Williams (Allen and Unwin, London) pp 15-34

Sorkin M (Ed.), 1992 Variations on a Theme Park (Hill and Wang, New York)

Tekeli İ, 1998, "Türkiye'de Cumhuriyet döneminde kentsel gelişme ve kent planlaması" [Urban development and city planning in Turkey's Republican era] 75 Yılda Değişen Kent ve Mimarlık [Changes in urban areas and architecture in 75 years] (Tarih Vakfı Yayınları, İstanbul) pp $1-24$

Ulusoy Z, 1993, "Collaboration among actors: a case of neighborhood rehabilitation", in Proceedings of Redevelopment and Regeneration of Urban Areas-International Experiences VIIth AESOP Congress Eds T Marszal, T Markowski (Lodz University Press, Lodz)

Ulusoy Z, 1998a, "Conflicting interests in revitalization: changing character of the Ankara Citadel", presented at Shelter and Revitalization of Old and Historic Urban Centers, International Conference, Havana, Cuba; copy available from the author

Ulusoy Z, 1998b, "Housing rehabilitation and its role in neighborhood change: a framework for evaluation" Journal of Architectural and Planning Research 15243 -257 
Ulusoy Z, Erendil A, 1999, “The inhabitants and consumers of the Ankara Citadel”, paper presented at Middle East Studies Association Conference, Washington, DC; copy available from the authors

Urry J, 1990 The Tourist Gaze: Leisure and Travel in Contemporary Societies (Sage, London)

Urry J, 1995 Consuming Places (Routledge, New York)

Zukin S, 1991 Landscapes of Power (Johns Hopkins University, Baltimore, MD) 